\title{
The Ethics of Engaged Pedagogy: A Comparative Study of Watsuji Tetsurô and bell hooks
}

\section{Anton Luis Sevilla}

\begin{abstract}
This article is a comparative study of bell hooks's "engaged pedagogy" with Watsuji Tetsurô's systematic ethics. The purpose of this comparison is twofold. The first reason is to examine the relational view of ethics that underlies hooks's thought in order to explore her deliberately "un-academic" work in a philosophically rigorous way. The second reason is to examine the fundamental connections of Watsuji's ethics of human existence to an education for human becoming. This comparison will be carried out in two stages. First, I will examine the connections of hooks and Watsuji on the level of society and relational structures. Second, I will delve deeper into the existential/spiritual level in the ethics/education of emptiness.
\end{abstract}

Keywords: Hooks, Watsuji, bell hooks, critical pedagogy, Buddhism

\section{Introduction}

$\mathrm{I}$

$\mathrm{n}$ this article, I shall be exploring the "engaged pedagogy" of bell hooks and the "ethics of emptiness" of Watsuji Tetsurô through a comparative study of key themes that appear in their work. This serves two purposes: The first purpose is to clarify the theoretical and philosophical grounds of hooks's astute but casual (and deliberately "un-academic") critique of contemporary educational trends, and in so doing highlight the importance of engaged pedagogy in more scholarly domains. I think this cannot be accomplished using a primarily individualist or universal mode of ethics (as is common with most readings of deontology or utilitarianism) but is better served by a relational form of ethics that stresses concrete relationships as the site of ethical character and behavior. I think Watsuji's ethics is particularly well suited for this task.

Second, while clarifying hooks's pedagogy via Watsuji, this article

(c) 2016 Anton Luis Sevilla

http://www.kritike.org/journal/issue 18/sevilla june2016.pdf

ISSN 1908-7330

(cc) $\mathrm{BY}-\mathrm{NC}-\mathrm{ND}$ 
also examines the fundamental connection between Watsuji's ethics and education - the human becoming (Jp. ningen seisei) necessary in order to realize Watsuji's vision for human being (Jp. ningen sonzai). This will both highlight Watsuji's practical applications as well as develop them further.

However, allow me to point out the practical context behind these theoretical concerns. While this situation is likely shared by other former colonies in Asia and the Americas, the Philippines is in the difficult position of having a culture with both individualist as well as group-centric (pakikisama) elements. It also has a political situation that requires the development of both individual criticality as well as improved national consciousness and solidarity. ${ }^{1}$ This situation is perhaps further complicated by an overwhelming focus on the individual and the universal in philosophical discourse, often to the neglect of intermediary elements like the family, the ethnic group, or the state. ${ }^{2}$ Many philosophers and pedagogues have been working to address this one-sidedness, and this article is part of the broader project of suggesting an ethical and educational model that accounts for and addresses both the individualist (liberal) and collective (communitarian) aspects needed for our flourishing.

I will begin this article by introducing the two thinkers. I will then proceed to do an analysis of their ideas. First, on the level of the structures that govern the relationship between individuals and groups, I will examine hooks's view of nurturing criticality through the mutual recognition of subjects. Then, I will compare this to Watsuji's notion of the double-negation of individuality and totality, and suggest points in which each system of thought can contribute to the other. Second, I will proceed deeper to the murkier domain of spiritual/existential depth. There, I will discuss hooks's idea of "engagement" as a spiritual, healing relationship. I will analyze this through Watsuji's view of emptiness, and what it means to share in emptiness via culture.

\section{The Structure of Education and Ethics}

These two thinkers may seem to have very little in common, and as far as I know there is no research connecting the two. ${ }^{3}$ But I argue that upon

\footnotetext{
${ }^{1}$ For example, see Agustin Martin G. Rodriguez, Governing the Other: Exploring the Discourse of Democracy in a Multiverse of Reason (Metro Manila: Ateneo de Manila University Press, 2009).

2 This cultural schizophrenia is discussed in Anton Luis Sevilla, "Gaijin Philosophy and the Problems of Universality and Culture: Conversations with Kasulis, Watsuji, and Sakai," Hakusan Furusato Bungakushô Dai 29 kai Akegarasu Haya Shô nyûsen ronbun (Ishikawa, Japan: Hakusanshi kyôiku iinkai, 2013), 29-58.

${ }^{3}$ However, I owe the connection between bell hooks and Watsuji Tetsurô to the following, which mentions but does not develop this connection: Erin McCarthy, Ethics Embodied:
} 


\section{ETHICS OF ENGAGED PEDAGOGY}

closer examination, they can mutually reinforce each other in many ways. Here, I focus on two main issues. First is the "double-negative" movement as it occurs in the structure of education.

\section{bell hooks's Vision for Education}

In Teaching to Transgress (1994), bell hooks begins with her experience of racially segregated education. She grew up right during the turning point of racial integration policies in the apartheid South (of the United States of America), and went through her elementary and middle school years in an all-black environment. In schools like Booker T. Washington, her experience of education was one that was as personal as it was political. Almost all her teachers were black women, and as members of a marginalized race, they taught their students with a passionate sense of purpose in hopes of liberating black America from its oppression. "We learned early that our devotion to learning, to a life of the mind, was a counter-hegemonic act, a fundamental way to resist every strategy of white racist colonization." 4 And in order to teach their students in such a liberatory manner, these teachers engaged their students: got to know the students and their families, and responded to them on the basis of that singular recognition.

With racial integration, this engaged and liberatory sort of teaching disappeared. Bussed to white schools, studying under mostly white teachers and alongside white classmates, black students were exposed to a very different notion of education. According to hooks, education became merely about transmitting information, with no real sense of concern for, nor cultivation of the students themselves. hooks describes this kind of education as the "banking system of education," 5 where education is characterized by knowledge as mere information, which is simply memorized by students and regurgitated come examination time. She describes this education as acritical and remarkably boring-not due to a lack of entertainment but due to the absence of any attempt to make it connect to the inner lives of each student.

This terminology ("banking") shows her debt to the founder of critical pedagogy, the Brazilian educator Paulo Freire, ${ }^{6}$ who opposed the "banking system of education" because he believed it was primarily a tool for maintaining systems of oppression. The method of lecturing to docile

\footnotetext{
Rethinking Selfhood through Continental, Japanese, and Feminist Philosophies (Lanham: Lexington Books, 2010), 97-99.

4 bell hooks, Teaching to Transgress: Education as the Practice of Freedom (New York: Routledge, 1994), 2.

${ }^{5}$ Ibid., 5.

${ }^{6}$ For a brief introduction to Freire, see Madonna M. Murphy, "Paulo Freire (19211997)," in The History and Philosophy of Education: Voices of Educational Pioneers (New Jersey: Pearson, 2006), 383-391.

(C) 2016 Anton Luis Sevilla http://www.kritike.org/journal/issue 18/sevilla june2016.pdf ISSN 1908-7330
}

(c) BY-NC-ND 
students acknowledges only the subjectivity of the teachers, and thus reinforces a sense of subservience on the part of the students. This allows oppression to go unchecked. Against this banking method, Freire suggested a "problem posing method," where the teacher presents problems, which students try to solve together with the teacher through multi-directional communication and dialogue. Here, the object and method of learning is open to negotiation. In this way, students learn not mere information, but knowledge connected to their own subjectivity and their lived praxis.

hooks, who studied with, collaborated with, and critiqued Paulo Freire, ${ }^{7}$ was deeply influenced by his theory of education. However, her approach to critical pedagogy has a slight twist. In her version, which she refers to as "engaged pedagogy," there is a much stronger focus on emotional elements of a classroom:

The first paradigm that shaped my pedagogy was the idea that the classroom should be an exciting place, never boring. And if boredom should prevail, then pedagogical strategies were needed that would intervene, alter, even disrupt the atmosphere. Neither Freire's work nor feminist pedagogy examined the notion of pleasure in the classroom. ${ }^{8}$

Her books all suggest, from different angles, how to make pedagogy more exciting, and thus more engaged-emotionally, intellectually, and even spiritually-with students and their experiences. There are four main elements she suggests here. ${ }^{9}$ First, an exciting class cannot be stuck to a set agenda. Rather, it must have the flexibility to respond to the changing needs of the class, to dwell on things as is necessary, and to even skip over other things when they are deemed to lack a real connection with the class. This, thus, depends on a second element, that each student be seen not merely as an individual but as a singularity. ${ }^{10}$ Because each student has a different context and trajectory, a class that is truly interesting must be flexible in responding to this singularity. However, no matter how much the teacher tries to respond to each student, if the students resist this and content themselves with desiring "mere information," it is impossible for the class to

${ }^{7}$ See hooks, "Chapter 4: Paulo Freire," in Teaching to Transgress.

8 hooks, Teaching to Transgress, 7 .

${ }^{9} \mathrm{Ibid} ., \mathrm{7}-11$.

${ }^{10}$ I use "singularity" in the way used by Jacques Derrida and Jean-Luc Nancy, in order to indicate the individual that, while radically relational, is unique and irreplaceable, and hence irreducible to the "individual" that is merely a unit of something universal (like reason or utility or biological existence).

(C) 2016 Anton Luis Sevilla http://www.kritike.org/journal/issue 18/sevilla june2016.pdf ISSN 1908-7330 


\section{8}

ETHICS OF ENGAGED PEDAGOGY

be exciting. This shows a third element, that the responsibility for an exciting class is not located merely in an individual but between individuals. This connects to a fourth element: an exciting class must be a place of the mutual recognition of subjects, where each person learns to value the other and to respond as one subject to another.

Only when these four elements-flexibility, responsiveness to singularities, mutual responsibility, and mutual recognition-are present can a class be truly engaging. Thus, hooks's vision for exciting education is not a call for entertainment or "emotional labor," but rather of authentic intersubjective connection in a manner that mutually cultivates criticality.

\section{Watsuji and Relational Ethics}

The idea of a class that is engaging and engaged seems intuitively appealing, but a closer look at it shows that it is rather complex, if not confusing. What does it mean to be responsive to a student as a singularity? What does it mean for responsibility to be shared in a pedagogic situation? How can one have mutual recognition between singularities? These elements can be clarified by examining the structure of human relationships in hooks's view of how education should be. But hooks does not directly discuss such a structure.

In order to examine this structure, I wish to turn to Watsuji Tetsurô, and suggest features of his ethics that might reveal the underlying structure to the relationships hooks argues for.

1. The Dual-Structure. hooks's vision of pedagogy demands a curious interlinking of both individuality and totality, of criticality and solidarity. hooks sees that students need to learn to be critical, to get beyond the established ways of thinking of the group, and to think for themselves. However, this does not imply that students become anti-social monads, concerned only for themselves. Rather, she tries to create a connection between people as creative members of society.

One of Watsuji's insights is to point out that while both individuality and totality are necessary for human existence, it is no simple matter putting these two together. What does it mean to combine these two incongruous elements, as hooks seems to do?

The relationship with the other that is now under consideration is a negative relationship in both cases. The essential feature characteristic of the independence of an individual lies in rebelling against the whole, and the essential feature characteristic of the wholeness of

(c) 2016 Anton Luis Sevilla

http://www.kritike.org/journal/issue 18/sevilla june2016.pdf

ISSN 1908-7330

(cc) BY-NC-ND 
the whole lies in its negating the independence of an individual. Hence, an individual is one whose individuality should be negated for the sake of the whole that is to be established, and the whole is that ground against which an individual rebels to establish itself. ${ }^{11}$

The only way one can learn to think for oneself is to be able to gain some distance from the collective, which is why children leave home and why ascetics move into the mountains. However, the only way to realize solidarity is to suspend one's individual differences, at least to a certain extent. In other words, if one insists on speaking a language not shared by others, or if one refuses to adjust to shared cultural or even moral codes, that is, if one insists on one's difference (Fil. ayaw makisama ${ }^{12}$ ), then solidarity becomes impossible.

How then is creative solidarity possible? For Watsuji, such a creative solidarity is only possible through the tensional but productive relationship of individuality and totality, where one distances oneself from society in order to see the demands of the totality that other members might not realize, then negating one's separateness by trying to integrate this individual realization with the group. This cycle between individuation and recommitment continues infinitely as we try to dynamically realize a society of togetherness that at the same time makes space for the individual's creative capacities. However, this cycle can often be difficult, and pioneers can be ostracized and martyred in the course of trying to integrate their ideas into the whole. ${ }^{13}$

I suggest we can understand hooks's view of engaged pedagogy as calling for such a "dual-negative structure," where individuals are given room to individuate and realize their unique perspectives, but are called to return to challenge the whole, in an endless process of critical individuation and creative solidarity.

However, hooks's discussions suggest the need for a social basis of criticality itself, which Watsuji tends to lack. During Watsuji's time, one strong tradition in education was to devote a long period of time adhering to set forms (kata). It is only after having perfected the form that a student could

\footnotetext{
${ }^{11}$ Watsuji Tetsurô, Watsuji Tetsurô's Rinrigaku: Ethics in Japan, trans. by Robert E. Carter and Yamamoto Seisaku (Albany: State University of New York Press, 1996), 101-102.

12 The Filipino translations show an emotional nuance that the English tends to lack. Insisting on difference seems almost a virtue in English. But ayaw makisama means a refusal to partake in togetherness by insisting on one's difference. The same nuance is seen in the Japanese phrase jibun katte.

${ }^{13}$ For more on the idea of creative solidarity and the tension of individual and group, see Anton Luis Sevilla, "Watsuji's Balancing Act: Changes in His Understanding of Individuality and Totality from 1937 to 1949," in Journal of Japanese Philosophy, 2:1 (2014), 105-134.
} 
dare to go beyond the form. ${ }^{14}$ This made it very difficult for all except the most established experts to individuate and try to creatively contribute to the whole without risking social backlash and even martyrdom.

What hooks suggests is that without the support of the community itself, most individuals will not even have the strength to turn away from their group on their own, with the exception of a few rebels (and pioneers). In order to create a society that allows for self-criticism and growth, we need to be able to educate criticality (and not just hope that it appears somehow). We need to teach the young that it is acceptable to think differently, that it is good to criticize.

This inter-subjective education requires a much deeper sort of bond than mere pakikisama (Jp. nakayoshi, En. getting-along). Rather, it requires a deep connection between singularities that creates a space of trust that allows for difference.

2. Trust and Truth. This brings us to the second point of contact between Watsuji and hooks: trust and the truth. Part of Watsuji's attempt to free ethical theory from its one-sided individualism was to show how ethical acts are not merely responses to some remote ideal (like a categorical imperative or to an axiological system) or to one's own utilitarian needs, but a truthful response to the trust of a concrete other. ${ }^{15}$ However, one of Watsuji's innovations with this idea of trust and truthfulness was to see it as not grounded merely in individual goodness nor in social convention, but in the dynamic interplay of both. This is clear, for instance, when one makes promises to another. While in general, one trusts on a social level that the other will do what he or she promises, there are times when the circumstances change, and doing what one promised actually harms the other party. (A classic Greek example is when a friend lends you a weapon on the condition that you return it when he needs it, and comes to take it back while clearly in a fit of rage.) While many might see this as a failure of the trust relationship, Watsuji sees this as the very unfolding of a deeper form of trust: Not "I trust that you will do as you promised (social convention)," nor "I trust that you will do what is right, regardless of your promises," but "I trust that you will bring your conscience to bear upon the very promises that bind us, that you will respond to me both as a thou, and as part of 'we.'"

hooks's vision of educating criticality is, thus, a concrete expression of this "dual-structure of trust," where the teacher trusts that the student will learn, but at the same time learn for him/herself in a critical manner. The

\footnotetext{
${ }^{14}$ Japan Ministry of Education, Kokutai no Hongi: Cardinal Principles of the National Entity of Japan, trans. by John Ownen Gauntlett, ed. by Robert King Hall (Cambridge: Harvard University Press, 1949), 157. Note too that Watsuji himself was involved in this publication.

${ }^{15}$ See Watsuji, "Trust and Truth," in Ethics in Japan, 265-282.
}

(c) 2016 Anton Luis Sevilla http://www.kritike.org/journal/issue 18/sevilla june2016.pdf

ISSN 1908-7330

(c) BY-NC-ND 
truthful response of a student then includes both the receptive openness to the demand to learn and the active criticality of taking that learning beyond its given state.

3. Relational Responsibility. Furthermore, for Watsuji, truthfulness is a response to trust, which means that without trust, truthfulness is not even possible. This is what makes Watsuji's ethical system radically relational. In such a model, "good" cannot be accomplished by the good will standing alone before the categorical imperative, nor the virtuous person realizing the values of society. Rather, good happens "between" people, the first step through trust and the second step through truthfulness. Watsuji gives the concrete example of the parent-child relationship: If a child does not trust his/her parents, the parents will not have the opportunity to raise their children filially (Jp. kô). In the same way, if the parents do not trust that the child has learned from his/her upbringing, the child will not have the opportunity to mature and show filial piety (Jp. oyakôkô) to his/her parents. Thus, filial piety is not a virtue of a child or of a parent but between parents and children. ${ }^{16}$

In the same way, one cannot account for the virtue of "engaged teaching" in the subjectivity of the teacher alone. No matter how much a teacher may pour his/her heart out to the students, if they do not open up to the teacher and allow themselves to be moved, to share in the journey offered, then "engaged pedagogy" remains unrealized. There is no "good teacher" without good students. In many western theories (like deontology, virtue ethics, or even some readings of Levinas), this may seem like an abdication of responsibility. But from the point of view of Watsuji and hooks, the insistence that responsibility should be shouldered by an "I" faced with a "thou" already presumes that the I-ness of the I can exist without its relationship with the thou, and thus prematurely closes the singularity unto itself. Through the discourse of mutual responsibility, one does not abandon one's responsibility, but rather recognizes its fundamentally relational character, and the contingency and tragedy that such a relationality might entail.

\section{The Unity of Ethics and Education}

Above, we have seen how bell hooks's engaged pedagogy can be understood through Watsuji's radically relational ethics, particularly in the ideas of the dual-negative structure, trust, and truth. But at the same time, it suggests that education is indispensable for ethics. In Watsuji's view, ethics is

${ }^{16}$ See Watsuji Tetsurô, Watsuji Tetsurô zenshû, vol. 10 (Tokyo: Iwanami Shoten), 399402.

(C) 2016 Anton Luis Sevilla

http://www.kritike.org/journal/issue 18/sevilla june2016.pdf

ISSN 1908-7330

(cc) BY-NC-ND 


\section{2}

ETHICS OF ENGAGED PEDAGOGY

something that is impossible without community. By bringing ethics home to concrete communities like families, towns, and nations, he not only tries to cure ethical theory of its abstractness, but also tries to rescue relationality from its blindness to its own worth. Every relationship bears the possibility of being the ground for the realization of the good. Each and every relationship can be a space for self-emptying (Jap. jiko o kûzuru), for love.

However, can there be community without education? In Democracy and Education (1916), John Dewey writes:

Society not only continues to exist by transmission, by communication, but it may fairly be said to exist in transmission, in communication. There is more than a verbal tie between the words common, community, and communication. Men live in a community in virtue of the things which they have in common; and communication is the way in which they come to possess things in common. ${ }^{17}$

Not only is social life identical with communication, but all communication (and hence all genuine social life) is educative. To be a recipient of a communication is to have an enlarged and changed experience. One shares in what another has thought and felt and in so far, meagerly or amply, has his own attitude modified. ${ }^{18}$

To put it simply, education creates continuity and builds connections amongst human beings. In its broadest sense, it is the sharing (Fr. partage $)^{19}$ of people that creates togetherness; it is communication as "communification." Society lives in this communication, in the simple education that occurs between friends, between siblings, between parent and child. The educational system, in all its complexity, has grown from this fundamental need for life and experience to be shared.

This has radical implications for Watsuji's thought, for that means that ningen (the human as both individual and social) is inseparable from education. Education is that which makes community possible, and hence what makes ethics possible. And thus, each educative space-from the

${ }^{17}$ John Dewey, Democracy and Education: An Introduction to the Philosophy of Education (New York: The Macmillan Company, 1916), 5.

18 Ibid., 6.

${ }^{19}$ As in Jean-Luc Nancy's idea of the sharing of singularities in their being-singularplural. See Jean-Luc Nancy, The Inoperative Community, trans. by Peter Connor, Lisa Garbus, Michael Holland, and Simona Sawhney (Minneapolis: University of Minnesota Press, 1991).

(c) 2016 Anton Luis Sevilla

http://www.kritike.org/journal/issue 18/sevilla june2016.pdf

ISSN 1908-7330

(c) $\mathrm{BY}-\mathrm{NC}-\mathrm{ND}$ 
classroom to the home to the internet-bears the possibility of being the space for cultivating the dual-structure of criticality and solidarity, of the trust between subjects that makes space for truth.

\section{Emptiness and Engagement}

Above, we have examined the connections between Watsuji and hooks on the level of structure, as seen in the interaction between individuality and totality. However, interwoven within hooks's engaged pedagogy are various ideas such as the sacredness of teaching, care for the soul, spiritual community, and so forth. These are ideas that are not easily discussed within the ambit of secularist structural discourses. Rather, they require a depth dimension, one that we might call the "spiritual" or "existential" dimension.

\section{Engaged Pedagogy}

In the chapter on "Engaged Pedagogy," bell hooks opens with the following words:

To educate as the practice of freedom is a way of teaching that anyone can learn. That learning process comes easiest to those of us who teach who also believe that there is an aspect of our vocation that is sacred; who believe that our work is not merely to share information but to share in the intellectual and spiritual growth of our students. To teach in a manner that respects and cares for the souls of our students is essential if we are to provide the necessary conditions where learning can most deeply and intimately begin. ${ }^{20}$

Where does this vision of education come from? If hooks's vision of "exciting education" as a resistance to the tedium of the banking system of education comes from Paulo Freire, the notion of education as "engaged," as a spiritual relationship between teacher-students and student-teachers, comes from her reading of Thich Nhat Hanh.

Thich Nhat Hanh (Thích Nhất Hạnh, 1926- ) is a Vietnamese Zen Buddhist monk who became one of the most famous figures in the struggle to end the Vietnam War. He coined the term "Engaged Buddhism" to refer to a Buddhism that, in every aspect of its contemplative practice, is engaged with

${ }^{20}$ hooks, Teaching to Transgress, 13.

(C) 2016 Anton Luis Sevilla

http://www.kritike.org/journal/issue 18/sevilla june2016.pdf

ISSN 1908-7330 


\section{ETHICS OF ENGAGED PEDAGOGY}

the suffering of all human beings as they go through their everyday lives. ${ }^{21}$ He thus tried to heal the gap between the spiritual practices of householdleavers with the compassion for householders.

I see three core elements to hooks's appropriation of Engaged Buddhism: First, the notion of healing in education; second, the notion of the wholeness and well-being of the teacher; and third, the unity of theory and praxis that founds these.

1. Healing Education. If a teacher is not merely giving information but opening up real problems shared by both teacher and student and creating a space to cultivate criticality, then the teacher is not merely connecting with the intellectual life of the student but with the entire human being he/she is faced with. The teacher is caring for the whole student as he/she wrestles with reality, a dynamic of the spirit that has corporeal, volitional, and affective components in addition to mere cognitive ones. This "intimate learning" is what requires hooks's (weighty) demand for the "care of the soul" and of "spiritual growth": by soul/spirit, she is not referring to an isolated part of the human psyche, but rather to the human being in its wholeness.

Caring for the student as a whole person is thus something closer to "healing." She writes, "In his work, Thich Nhat Hanh always speaks of the teacher as a healer .... Thich Nhat Hanh offered a way of thinking about pedagogy which emphasized wholeness, a union of mind, body, and spirit." Education heals the brokenness of an individual in his/her imagined separation from the world, the fractures of experience. It heals the fragmentation of mind, body, and spirit by cultivating an environment wherein the questioning of the mind is unified with the needs and movements of the body and the spirit. And it heals the division of self and other by creating an environment where restoration of one's own integrity is shared with others through communal learning and discussion. In Teaching Critical Thinking (2009), hooks refers to this as "sharing one's inner light," a process in which people share their process of spiritual growth in a space of radical openness and mutual learning. ${ }^{22}$ (This wholeness and communality is something that Dewey's theory of interest and educational epistemology suggests but does not explicitly develop.)

In Teaching Community (2003), hooks's view is succinctly captured in her citation of Parker Palmer:

\footnotetext{
2009), 5-6.

${ }^{21}$ Sallie B. King, Socially Engaged Buddhism (Honolulu: University of Hawaii Press, ${ }^{22}$ bell hooks, Teaching Critical Thinking: Practical Wisdom (New York: Routledge, 2010), 20.

(c) 2016 Anton Luis Sevilla http://www.kritike.org/journal/issue 18/sevilla june2016.pdf ISSN 1908-7330
}

(c) $)$ BY-NC-ND 
Education is about healing and wholeness. It is about empowerment, liberation, transcendence, and renewing the vitality of life. It is about finding and claiming ourselves and our place in the world .... I want to explore what it might mean to reclaim the sacred at the heart of knowing, teaching, and learning - to reclaim it from an essentially depressive mode of knowing that honors only data, logic, analysis, and a systematic disconnection of self from world, self from others..$^{23}$

We see here the connection of her critique of the banking system of education (as something that fragments the knowing self from the experiencing self) and the stress on the "sacred" foundation of education.

2. The Wholeness of Teachers. What demands are made on teachers, if they are to participate in this sort of education? hooks writes, "Thich Nhat Hanh emphasized that 'the practice of a healer, therapist, teacher or any helping professional should be directed toward his/herself first, because if the helper is unhappy, he or she cannot help many people.'"24 If a professor has psychological blocks surrounding particular academic issues (for instance, if a sexist teacher is teaching a class on feminism), it will be difficult for the professor to help students approach these issues with a sense of openness (and the tendency will be to talk about the topic in as detached and objective a manner possible, or distort it in order to cover up the professor's own guilt). While this does not require that an educator be fully healed of all issues, it requires that the educator at least be honestly engaged in dealing with these blocks. This is similar to the practice of psychotherapy, wherein the person of the counselor and his/her wholeness and willingness to deal with his/her own psychological issues play a decisive role in his/her ability to deal effectively with the problems of a patient. ${ }^{25}$

On one hand, the thought of being accountable not only for the information one carries but for one's very personhood can weigh heavily on the minds of professors. hooks writes:

Part of the luxury and privilege of the role of teacher/professor today is the absence of any requirement that we be self-actualized. Not surprisingly,

\footnotetext{
${ }^{23}$ Quoted in bell hooks, Teaching Community: A Pedagogy of Hope (New York: Routledge, 2003), 179-180

${ }^{24}$ hooks, Teaching to Transgress, 15.

${ }^{25}$ See Gerald Corey, "The Counselor: Person and Professional," in Theory and Practice of Counseling and Psychotherapy, $8^{\text {th }}$ ed. (Belmont, CA: Thomson Brooks/Cole, 2009), 16-35. 
professors who are not concerned with inner well-being are the most threatened by the demand on the part of students for liberatory education, for pedagogical processes that will aid them in their own struggle for self-actualization. ${ }^{26}$

But while it may be difficult for those who have "sacrificed their humanity for tenure" to respond to the demand to cultivate humanity via their own humanness, engaged pedagogy is not only for the sake of students. Just as the banking system of education tends to "objectify" students into mere repositories for information, it objectifies teachers as well into mere sources of information and implementers of curricula, making it difficult for the vocation of teaching to be a path of inner growth.

hooks writes, "The objectification of the teacher within bourgeois educational structures seemed to denigrate notions of wholeness and uphold the idea of a mind/body split, one that promotes and supports compartmentalization." 27 Perhaps even more than students, teachers-intraining and graduate students are often forced into a massively competitive environment, with unhealthy work hours, where they barely have time to digest the information they learned due to the speed in which they have to assimilate information. This can result in an academic culture that tends to denigrate any clear personal connection and sense of value-judgment in one's research, for the sake of maintaining "objectivity." Conversely, this can lead to very personal theories (like black feminist theory made by a black woman) as being relegated to the realm of the particular-as mere personal narratives that have nothing to do with "universal theory." 28

Recently, there has been a spate of news articles on the rates of suicide and psychological disorders in graduate school. While this needs to be supported with empirical studies, perhaps one can hypothesize that engaged pedagogy's bridging of personal life and theory might prevent the former from being sacrificed for the latter and improve the well-being of teachers and future teachers as well.

3. The Unity of Theory and Praxis. A third point we see here is that "healing education" and the wholeness and well-being of teachers point to the unity of theory and practice. In hooks, we see there are only two logical explanations for why the banking system of education would teach

${ }^{26}$ hooks, Teaching to Transgress, 17.

${ }^{27}$ Ibid., 16.

${ }^{28}$ These examples can be seen in various stories shared by hooks all throughout the teaching trilogy. These stories show, in a personal fashion, hooks's own experience of discrimination, and the forcible separation of the personal and the "universal."

(c) 2016 Anton Luis Sevilla http://www.kritike.org/journal/issue 18/sevilla june2016.pdf ISSN 1908-7330 
information and theory alone, without connecting them to real life. The first is the idea that information and theory can be learned independently from real life, and then applied to real life situations in the future. Dewey's Democracy and Education is almost entirely dedicated to debunking this on the basis of educational epistemology and psychology. The second possibility is that the educational system does not intend to help students become selfactualized individuals. Rather, information is merely a convenient and arbitrary tool to have students compete with each other and thus allow for stratification (or a reproduction of preexisting strata) by sorting the wheat from the chaff. ${ }^{29}$ This is the very "oppression" that Paulo Freire tries to address in Pedagogy of the Oppressed (1968).

The separation of theory from praxis is thus either epistemologically mistaken or a tool for domination. hooks argues against this separation, asserting that theory is something that is born from life and is inseparable from praxis. She writes,

I came to theory because I was hurting - the pain within me was so intense that I could not go on living. I came to theory desperate, wanting to comprehend-to grasp what was happening around and within me. Most importantly, I wanted to make the hurt go away. I saw in theory then a location for healing. ${ }^{30}$

For hooks, theory is a path to allow the self to find its home in the world through understanding. There is thus an essential connection between hooks's idea of theory and the idea of contemplation in Thich Nhat Hanh: Both theory and contemplation are responses to the fundamental human situation of suffering and separation, and are attempts to recover the original unity of self and world.

In Thich Nhat Hanh, the realization of the true nature of self as "empty" necessarily results in compassion: One sees one's connection to other people and their suffering, and tries to help them be free from suffering as well. ${ }^{31}$ Thus contemplation is tied to compassion. In the same way, in Freire, the theoretical understanding of the human condition of oppression and the resulting alienation of both the oppressor and the oppressed is inseparable from the praxis of overcoming this alienation. ${ }^{32}$ hooks takes both these elements and thus argues for a view of theory that is both inspired by liberation and that tries to realize liberation both individually and

\footnotetext{
${ }^{29}$ hooks, Teaching to Transgress, 64 .

${ }^{30} \mathrm{Ibid} ., 59$.

${ }^{31}$ King, Socially Engaged Buddhism, 8-9.

32 hooks, Teaching to Transgress, 14.
} 
collectively.

\section{The Culture of Emptiness}

Watsuji's brief remarks on the idea of education are found interspersed amongst his discussions of culture. People who share in culture are a cultural community, or a "spiritual community" (seishinteki kyôdôtai) in the German sense of geistliche: anyone who shares in my Geist is my friend. ${ }^{33}$ This is important because cultural community is the most inclusive: Unlike blood relations or growing up together, culture, the Geist of a community can be learned. Thus in Ethics III, this spiritual community plays a key role in bridging even the gaps between nations, in an attempt to form an international order. The most inclusive sense of community-and correlatively, the most inclusive space for realizing ethics-relies on the mediation of culture.

Watsuji talks about four aspects of culture: language, art, scholarship, and religion. There is nothing abstract or "high-culture" about these aspects-by learning these, an individual acquires the capacity to communicate and to share in the sensibilities, knowledge, and beliefs of a group, allowing for a sense of shared identification with others. These four elements are learned in every aspect of social life, but the institution that takes the transmission of these as its goal is, of course, the educational system. ${ }^{34} \mathrm{He}$ writes,

In this way, these days, the people around us who call each other friends (yîjin) are usually acquaintances from "school." ... Even though schools may not truly realize a community of love for wisdom (chie no ai), people are still inculcated with the same knowledge and the same way of thinking as well as the same spiritual training (seishinteki kunren) in school. Though it may remain at this level, it is still the foundation for spiritual community. In other words, it is only on the basis of this

${ }^{33}$ Geist and seishin are nearly identical, but both are difficult to translate into English. They are translated as "mind" or "spirit," but can lead to misunderstandings. For example, geistliche and seishinteki mean "spiritual," but not in the religious sense of spirituality. It is closer to the use of Geist in geisteswissenschaft-literally, spiritual science, that includes philosophy, history, philology, social science, etc. So spiritual community means any community bound not merely physically but with these elements related to meaningfulness and mind.

${ }^{34}$ Some may argue that the school does not or should not teach religion. However, post-secularism has critiqued the idea that liberal democracy is religiously neutral. It has its own "beliefs" and values, which are taught by supposedly "secular" education systems. hooks also discusses these issues, but I leave this to another paper.

(C) 2016 Anton Luis Sevilla

http://www.kritike.org/journal/issue 18/sevilla june2016.pdf

ISSN 1908-7330

(cc) BY-NC-ND 
that people can arrive at the possibility of being friends. ${ }^{35}$

From the actual circle of people we call friends to the very possibility of spiritual community, education plays a key role in the propagation of a shared culture. However, Watsuji's view of culture has three key qualifications that would alter any idea of education that seeks to transmit it.

1. Returning to the Absolute. First, Watsuji sees culture as a return to the absolute. For instance, Watsuji does not see art as mere arbitrary expressions that are eventually canonized as a culture's aesthetic ideals. Rather, when an artist makes art, he or she is expressing "formless form" (katachi naki katachi) as form. As an expression in form, art is unique and singular, bearing the stamps of both the individual artist as well as his/her accumulated experiences of art. But as expressing formless form, art is grounded in something universal, something absolute. What is this formless form? Watsuji explains:

We must grasp this at the most foundational layer of human existence. Therein, humanity is originally one and transcends all distinctions (sabetsu). However, there too is the origin of all distinctions, and at the same time is all distinctions themselves. Because of this, human existence is, in its extreme, emptiness, and develops itself as a movement of return (kirai). Emptiness is the dynamic of emptying emptiness and becoming being $(y \hat{u})$, and emptying being and returning to emptiness. ${ }^{36}$

Formless form is none other than emptiness, which expresses both the fundamental unity of humankind-a unity captured by mystical experiences of Buddhist monks, Christian mystics, and Sufis alike-and at the same time the self-articulation of this unity as difference. The beauty of art comes from its attempt to express this dynamic through form. Similarly, scholarship (be it in the sciences or in the humanities) is an attempt to understand the absolute as truth, that is cognitively/epistemologically (rather than aesthetically). And religion is an attempt to directly return to this in terms of feeling and experience. ${ }^{37}$

The implication for this is that each element of culture has a certain depth. When teaching each subject of the curriculum-from Pythagorean geometry to Machiavelli's The Prince (1532) - one is teaching how individuals

${ }^{35}$ Watsuji, Zensh $\hat{u}$, vol. 10, 575. Translation by the author.

${ }^{36} \mathrm{Ibid}$., 544 . Translation by the author.

${ }^{37}$ Ibid., $540-560$.

(C) 2016 Anton Luis Sevilla http://www.kritike.org/journal/issue 18/sevilla june2016.pdf ISSN 1908-7330 
and communities tried to grasp the foundations of human existence, the truth beneath it all. Thus, learning too ought to have the spiritual character proper to the content. It is not a mere abstract gathering of information but, in a sense, a coming home to the foundation of human existence, guided by those who came before us. This task, as hooks argues, has a clearly sacred character.

2. The Unity of Culture in Emptiness. This brings us to a second point: The various facets of culture connect with each other at the root, and thus cannot be abstracted from each other without reducing them to a mere superficial resemblance of what they originally are. In Watsuji's view, art, science, and religion are fundamentally one (and language is a common element they all share) in that they are all attempts to express the absolute (which he refers to as emptiness) in taste, thought, emotion, and experience. And if one recalls, this "emptiness" is not only the ground of culture but the ground of ethics as well. This implies that the various factors of cultural experience and thus of human experience-cognitive, aesthetic, affective, volitional-are not separate, but are one as expressions of emptiness.

The implication of this for education is that first, the various subjects of the curriculum are united in this depth. If we are to communicate these subjects with this in mind, we must be careful not to lose the essential connectedness of the various specializations of the curriculum. Second, this unity is not merely within the curriculum, but between the curriculum and human life. Theory (the science of human life) cannot be separated from praxis (ethics), nor from the affective and aesthetic elements of human life (excitement, pain, etc.).

Finally, a unified curriculum that is rooted in the human yearning for the absolute cannot be merely for a loosely-knit "profit society," but must be committed to a deeper engagement between human beings. This is in line with Watsuji's critique of Gesellschaft as a "state of privation" of community. Influenced by Ferdinand Tönnies's Gemeinschaft und Gesellschaft, Watsuji argues that a truly ethical community cannot merely be a "profit society" wherein individuals band together in order to secure their egoistic interests.

Ningen sonzai makes its appearance in a defective form of solidarity. Here, societies of mutual interest arise (Gesellschaft), or what could be called egoistically connected societies. These societies, although drawing lessons concerning communal structure from the community of sonzai, do not make sonzai communal. Here, trust, sincerity, service, responsibility, obligation, and so forth are made use of formally but have no substance. That is to say, they are systems of social

(c) 2016 Anton Luis Sevilla

http://www.kritike.org/journal/issue 18/sevilla june2016.pdf

ISSN 1908-7330

(c) BY-NC-ND 
ethics, without thereby being socially ethical. For this reason, they can be called deprived forms of social ethics. ${ }^{38}$

This is something Watsuji found in the utilitarian, liberal, and capitalist view of society. He also saw its negative influence on schools.

The schools at present are extremely deficient in many things [in order to be a] community in scholarship (gakumon ni okeru kyôdôtai). Rather, they can be said to betray a strong Gesellschaft character. Scholarship is becoming a means for livelihood, and school is becoming a place for business (shokugyô). Rather than trying to come together (gôitsu) for the sake of scholarly inquiry, researchers compete for that position. Rather than trying to collaborate in their pursuit of knowledge, students do everything they can to get jobs. As a result, schools are even administered as profit-making enterprises. However, this shows that schools have lost their original meaning, and not that schools are originally as above..$^{39}$

While Watsuji did not directly discuss the ethical imperative of schooling in detail, we see that it plays an essential role in building an ethical community of shared tastes, beliefs, knowledge, and values - one that is lost with the degeneration of education into a mere means for capitalist society.

3. The Dual-Negative Structure in Culture. However, with the discussion of education's role in building cultural community as Gemeinschaft, one may worry that education is thus a form of indoctrination, wherein the individual is subjugated to the shared mindset of the whole. Wouldn't this be the very politics of domination that Freire and hooks clearly denounce? This is clearly not the case, however, if we examine a third point: For Watsuji, sharing in culture is dynamic-a constant re-expression of the inexpressible-that thus requires that one maintains the tension between creativity and solidarity.

This can be seen in Watsuji's idea of cultural products and cultural production. For Watsuji, cultural life is mediated by preexisting cultural products: books, novels, sculptures, theological treatises, and so forth. However, these are not shared in a static manner but are constantly

${ }^{38}$ Watsuji, Ethics in Japan, 25.

${ }^{39}$ Watsuji, Zensh $\hat{u}$, vol. 10, 575.

(C) 2016 Anton Luis Sevilla http://www.kritike.org/journal/issue 18/sevilla june2016.pdf ISSN 1908-7330 


\section{ETHICS OF ENGAGED PEDAGOGY}

reinvigorated through cultural production in which language, art, science, and religion are made anew. In this act of production, a singular individual, bearing the influences of the culture around him/her, tries to return directly to the absolute-the one, the true, the good, the beautiful. It is this personal insight that he/she tries to express and communicate in a way that connects but creatively reconstructs preexisting cultural products. Thus, new art is made, new theories are discovered, and fresh life enters even the traditional world of religion. ${ }^{40}$

What we see here then is that the sharing in cultural life is dynamic, and involves both individual creativity and solidarity with others. It does not reduce the individual to the collective, as the Gemeinschaft theory might make it seem.

The view of culture we have seen above can help us understand the spiritual/existential side of hooks's engaged pedagogy. Education conveys culture. But culture is not merely a special domain of "cultured people" but the means by which we connect with others in communities. It has to do with how we communicate, how we share in feelings and tastes, and how we coordinate our volitional lives with each other. Thus, there can be no separation between theory and praxis-everything we learn (theory) ought to be a means for life (praxis). But this "life" is not merely cognitive or economic. Rather, it has to do with how we relate with others with the entirety of our being. As such, education is involved with the entirety of the students' being. And this holism has a depth, in that all of these facets of culture are different ways of expressing the inexpressible, the very foundation of our being in emptiness. Thus, education becomes inseparable from an involvement with the soul, a nurturing and a healing of the entire person. (And while Watsuji fails to examine this point, such a holistic engagement would involve not only the whole student, but the whole teacher as well!)

However, this cultivation of the entire person cannot be one-sided. If our engagement with culture involves critique and creativity through each person's realization of emptiness, then culture must be conveyed in a way that it can be accepted, explored, and then critiqued and creatively transformed. This allows us to pull together both strands of hooks's engaged pedagogy - the critical communality she derives from Freire and the focus on wholeness and healing she derives from Thich Nhat Hanh. We engage the spiritual depths of human persons in a way that allows them to engage the culture they share from the depths of their being, and thus participate in a critical and creative way. It is only through this engagement that we can build a genuinely spiritual community, rather than a mere society of mutual self-

${ }^{40}$ For examples of this, see Watsuji, Zensh $\hat{u}$, vol. 10, 520, 551, 560.

(c) 2016 Anton Luis Sevilla

http://www.kritike.org/journal/issue 18/sevilla june2016.pdf

ISSN 1908-7330

(c) $)$ BY-NC-ND 
benefit.

\section{Conclusion}

In this article, we have examined two levels of bell hooks's vision of "Engaged Pedagogy." The first was the structural level, primarily influenced by Paulo Freire. It entailed four main elements in order to make a truly exciting and engaged education possible: flexibility, responsivity to singularities, mutual responsibility, and mutual recognition. We have seen how the structure of this relationship can best be understood via Watsuji Tetsurô's ethical theory, wherein ethics is seen as a realization of the dualnegative structure of individuality and totality, where truth is seen as a response to trust, and where goodness is realized in a purely relational manner. Individualist or universalist accounts of ethics as found in deontology, utilitarianism, or even virtue ethics (insofar as virtue is seen as an individual's virtue) would not be able to account for the relational structure hooks demands. ${ }^{41}$

The second level was spiritual/existential, this time largely influenced by Thich Nhat Hanh. It entailed three main elements: education as healing, the wholeness of the teacher, and the unity of theory and praxis. This too can be best understood through Watsuji's notion of culture (and education as the communication of culture). As the medium of human connections, culture is seen as tying together theory and practice. Furthermore, culture is seen as having a depth aspect, wherein all forms of culture are expressions of emptiness. Thus, an education that communicates such a culture would be a total involvement between student and teacher, including this sense of spiritual depth. And this culture, being something that is dynamically transformed, once again requires both criticality and solidarity-bridging the spiritual level to the structural.

Through this we have seen that while bell hooks may not articulate a metaphysics or a systematic theory of ethics, her view of education presumes a sophisticated relational ethics. Furthermore, we have seen that while concepts like "double-negation" and "emptiness" in Watsuji's ethics may seem ambiguous, this ambiguity is a direct response to the paradoxical challenges of becoming human. By examining them side-by-side, we can see that hooks's pedagogy is as astute as Watsuji's ethics is concrete.

However, this is not to say that these two thinkers are identical. Watsuji was not a feminist. At times, he was dangerously nationalistic and an

${ }^{41}$ It is also possible to link hooks's pedagogy with the ethics of care. However, I question the ability of care ethics, at least in the form Noddings presents it, to respond to existential crises and spiritual concerns, due to the overwhelming focus on "natural care" and forms of pain that are easily understood. I will leave this to another paper.

(C) 2016 Anton Luis Sevilla http://www.kritike.org/journal/issue 18/sevilla june2016.pdf ISSN 1908-7330 


\section{ETHICS OF ENGAGED PEDAGOGY}

enemy of multiculturalism. hooks would probably be uncomfortable with this, and her views of the "neutrality" of spirituality would probably be rejected by Watsuji. But what I wish to argue is that at the core of their projects lies the view of the human being, of reality, and of education that is characterized by a profound sense of relationality and depth, which is more than relevant today.

Faculty of Arts and Sciences,

Graduate School of Human Environment Studies (Education)

Kyushu University, Japan

\section{References}

Corey, Gerald, Theory and Practice of Counseling and Psychotherapy, $8^{\text {th }}$ ed. (Belmont, CA: Thomson Brooks/Cole, 2009).

Davidson, Maria del Guadalupe and George Yancy, Critical Perspectives on bell hooks (New York: Routledge, 2009).

Dewey, John, Democracy and Education: An Introduction to the Philosophy of Education (New York: The Macmillan Company, 1916).

Florence, Namulundah, bell hooks' Engaged Pedagogy: A Transgressive Education for Critical Consciousness (Westport, Connecticut: Bergin \& Garvey, 1998).

hooks, bell, Teaching Community: A Pedagogy of Hope (New York: Routledge, 2003.

Teaching Critical Thinking: Practical Wisdom (New York: Routledge, 2010).

Teaching to Transgress: Education as the Practice of Freedom (New York: Routledge, 1994).

Japan Ministry of Education, Kokutai no Hongi: Cardinal Principles of the National Entity of Japan, trans. by John Ownen Gauntlett, ed. by Robert King Hall (Cambridge: Harvard University Press, 1949).

Kincheloe, Joe L., Critical Pedagogy Primer (New York: P. Lang, 2004).

King, Sallie B., Socially Engaged Buddhism (Honolulu: University of Hawaii Press, 2009).

McCarthy, Erin, Ethics Embodied: Rethinking Selfhood through Continental, Japanese, and Feminist Philosophies (Lanham: Lexington Books, 2010).

Murphy, Madonna M., The History and Philosophy of Education: Voices of Educational Pioneers (New Jersey: Pearson, 2006).

Nancy, Jean-Luc, The Inoperative Community, trans. by Peter Connor, Lisa Garbus, Michael Holland, and Simona Sawhney (Minneapolis: University of Minnesota Press, 1991).

(C) 2016 Anton Luis Sevilla

http://www.kritike.org/journal/issue 18/sevilla june2016.pdf

ISSN 1908-7330

(c) $)$ BY-NC-ND 
Rodriguez, Agustin Martin G., Governing the Other: Exploring the Discourse of Democracy in a Multiverse of Reason (Metro Manila: Ateneo de Manila University Press, 2009).

Sevilla, Anton Luis, "Concretizing an Ethics of Emptiness: The Succeeding Volumes of Watsuji Tetsurô's Ethics," in Asian Philosophy, 24:1 (2014). "Education and Empty Relationality: Thoughts on Education and the Kyoto School of Philosophy," in Journal of Philosophy of Education [early view].

"Gaijin Philosophy and the Problems of Universality and Culture: Conversations with Kasulis, Watsuji, and Sakai," in Hakusan Furusato Bungakushô Dai 29 kai Akegarasu Haya Shô nyûsen ronbun 白 山ふるさと文学賞第二十九回暁烏敏賞入選論文 (Ishikawa, Japan: Hakusanshi kyôiku iinkai, 2013). "The Buddhist Roots of Watsuji Tetsurô's Ethics of Emptiness," Journal of Religious Ethics [forthcoming]. "Watsuji's Balancing Act: Changes in His Understanding of Individuality and Totality from 1937 to 1949," in Journal of Japanese Philosophy, 2 (2014).

Standish, Paul and Saito Naoko, eds., Education and the Kyoto School of Philosophy: Pedagogy for Human Transformation (Dordrecht: Springer, 2012).

Watsuji Tetsurô 和辻 哲郎, Fûdo: Ningengakuteki kôsatsu 風土一人間学的考察 (Tokyo: Iwanami shoten, 1991). Climate and Culture: A Philosophical Study, trans. by Geoffrey Bownas (Tokyo: Yushodo co., ltd., 1961). "Japanese Literary Arts and Buddhist Philosophy," trans. by Hirano Umeyo, in The Eastern Buddhist, New Series, 4:1 (1971). Watsuji Tetsurô's Rinrigaku: Ethics in Japan, trans. by Robert Carter and Yamamoto Seisaku (Albany: State University of New York Press, 1996).

Watsuji Tetsurô zensh $\hat{u}$ 和辻哲郎全集, 27 volumes, edited by Abe Yoshishige 安倍能成, et al. (Tokyo: Iwanami shoten, 1991-1992). 